\title{
"They went on the so-called front- line": Headteachers on the importance of teacher assistants supporting Roma students during Covid-19 pandemic
}

\section{Zbyněk Němec}

\begin{abstract}
Socially disadvantaged Roma students are one of the most vulnerable groups in education. Since the 1990s, one of the effective tools supporting the education of these students has been the job of teacher assistant (TA). The article presents the results of a study focused on the distance education of Roma students during school closures at the time of the Covid-19 pandemic in 2020. The research was based on semi-structured interviews with headteachers and other school staff from six elementary schools attended by socially disadvantaged Roma students. The aim of the study was to describe examples of good practice in distance education; the article focuses particularly on the contribution of teacher assistants, which consisted of: a) TAs establishing contact with students who do not attend online lessons; b) TAs helping to distribute printed learning materials to students, at schools as well as in the localities where the students lived; c) TAs providing one-to-one consultations for the students who were the most in need;

d) TAs helping students and their parents to learn how to use the programs necessary for online learning; e) TAs providing online tutoring for students; f) TAs helping teachers with the organization of teaching in smaller groups of students after the schools opened. The described examples of good practice should be the starting point for the
\end{abstract}


further professional development of teacher assistants and their involvement in the education of socially disadvantaged Roma students.

Key words: teacher assistant; Roma; socially disadvantaged students; distance education.

\title{
„Šli takzvaně do první linie“: Ředitelé o důležitosti asistentů pedagoga ve vzdělávání romských žáků během pandemie Covid-19
}

\begin{abstract}
Abstrakt
Sociálně znevýhodnění romští žáci představují jednu z nejvíce zranitelných skupin ve vzdělávání. Od 90 . let 20 . století je významným nástrojem podpory vzdělávání těchto žáků profese asistentů pedagoga (AP). Článek prezentuje výsledky studie zaměřené na distanční vzdělávání romských žákủ během uzavření škol v době pandemie Covid-19 v roce 2020 . Výzkum byl založen na semi-strukturovaných rozhovorech s pracovníky šesti základních škol navštěvovaných sociálně znevýhodněnými romskými žáky. Cílem výzkumu bylo popsat príklady dobré praxe v distančním vzdělávání; článek se soustředí specificky na prínosy asistentů pedagoga, které spočívaly v: a) AP zajištovali kontakt se studenty, kteří se neúčastnili online výuky; b) AP pomáhali distribuovat tištěné výukové materiály pro studenty, ve školách i v lokalitách, kde žáci žijí; c) pro nejvíce potřebné žáky AP zajištovali konzultace „jeden na jednoho“; d) AP pomáhali žákům a jejich rodičům naučit se používat programy potřebné pro online výuku; e) AP zajištovali pro žáky online doučování; f) po otevření škol AP pomáhali učitelům s organizací výuky v menších skupinách žáků. Popisované příklady dobré praxe by měly být východiskem pro další rozvoj profese asistentů pedagoga a jejich zapojení do vzdělávání sociálně znevýhodněných romských žáků.
\end{abstract}

Klíčová slova: asistent učitele; Romové; sociálně znevýhodnění žáci; distanční vzdělávání.

DOI: $10.5507 /$ epd.2021.022

\section{Introduction}

Being the largest and the most marginalized ethnic minority in Central Europe, socially disadvantaged Roma students should not lack the attention of educational research, 
especially in difficult times, like those connected with the school closures during the Covid-19 pandemic. Current studies already show that many schools were unable to establish contact with socially disadvantaged students during the period of distance learning (Charvát, Lang, Staveník, 2020).

In the Czech Republic, the Roma minority constitutes approximately 2.2 percent of the entire country's population and, according to qualified estimates, about half of the 240,000 Czech Roma live in a socially disadvantaged environment (Government Council for Roma Minority Affairs, 2019)' ${ }^{1}$ In the so-called socially excluded localities where the overall situation resulting from poverty, unemployment and other negative phenomena is by far the worst - the population increased between 2005 and 2015 from an estimated 60 to 80 thousand to approximately 95 to 115 thousand; according to a survey conducted for the Ministry of Labor and Social Affairs, about $40 \%$ of the population of these localities are children under 15 years of age and most of them are Roma (GAC, 2015).

As the number of socially disadvantaged Roma students in schools increases, attention needs to be paid to support measures in the education of these students - among which the role of teacher assistant is considered to be essential. And the importance of the teacher assistants' work is also confirmed by the experience of school closures due to the Covid-19 pandemic in 2020.

\section{Teacher assistants in the education of socially disadvantaged Roma students}

The profession of teacher assistance has a relatively long history in the education of socially disadvantaged Roma students in the Czech Republic: As early as 1997, the position of "Roma assistant" was established in some elementary schools - those were assistants who themselves originated from the Roma minority and were responsible for supporting the education of socially disadvantaged students (Němec, Šimáčková-Laurenčíková, Hájková, 2014). A few years later, this position was renamed "tutor - teaching assistant", and it was newly opened to non-Roma, though in practice, their support was further directed mainly to Roma children. In 2005, the position of assistant working with Roma students was officially merged with that of assistant supporting students with disabilities, and since then it has existed as "teacher assistant" (Němec et al., 2014).

At present, in the Czech Republic, the position of teacher assistant is defined as a support measure in the education of students with special educational needs. In ad-

On the other hand, it is still necessary to emphasize that half of the Roma in the Czech Republic: 1) are fully integrated into the majority society, 2) do not live in a socially disadvantaged environment, 3) and thus contradict the widespread prejudice based on the idea that the "ordinary Roma" is a resident of a socially excluded area. 
dition to students with disabilities, this support measure is also applied to „students in need of support in education due to different cultural and living conditions" (School Act; Decree No. 27/2016 Coll.). The importance of this profession is also indicated by the growing number of teacher assistants in Czech schools - according to statistics published by the Ministry of Education, the number of assistants in all types of schools increased from 17,725 employees in September 2017 to 24,270 assistants in September 2019 (MEYS, online, accessed 2020-11-29). Unfortunately, the statistics do not show how many of the total number of teacher assistants work with socially disadvantaged or Roma students, but some research studies suggest that approximately half of the teacher assistants provide in their practice at least some partial support to socially disadvantaged students (Hájková et al., 2018).

Various previous studies also clearly demonstrate the significant positive benefits of teacher assistants' work in the education of socially disadvantaged Roma students: Under normal - not pandemic - conditions, teacher assistants support these students during their classes, provide tutoring for Roma students, visit students' homes and families and thus facilitate communication between the Roma parents and schools, provide teachers with knowledge about ethnic minority culture and their students' social background; and, last but not least, these assistants, often being Roma themselves, can also serve as work and study role models for many socially disadvantaged Roma students (Němec et al., 2015, 2018). But what are the specific roles of these assistants when normal conditions change, schools are closed, and socially disadvantaged Roma students have to switch to distance learning?

\section{Methodology and the research sample}

The following text describes the findings of research ${ }^{2}$ focused on the issue of distance education and its implementation by schools with high numbers of socially disadvantaged Roma students.

Qualitatively oriented research was carried out in the period from September to October 2020. The three main research questions were focused on specific barriers, specific consequences and supporting tools / examples of good practice in the distance education of socially disadvantaged Roma students. In the beginning, data analysis worked with four categories (barriers / consequences / online support / offline support) and thirty-three basic codes. Already during the acquisition of the research data, and subsequently also during the analysis of this data, the kind of support provided

2 It was part of the research activities realized by the Department of Special Education, Faculty of Education, Charles University, in the project „Progress Q17 - Teacher training and the teaching profession in the context of science and research“ (in Czech:„Progres Q17 - Příprava učitele a učitelská profese v kontextu vědy a výzkumu“). 
by the teacher assistants proved to be not only frequently used, but often also played a crucial role - for this reason, a fifth additional category was created for the contribution of teacher assistants; the following text of the article focuses specifically on the outputs from this category. There were six elementary schools involved in the research sample $^{3}$ : Walnut Tree Elementary and Apple Tree Elementary are located in regions with a larger number of socially disadvantaged residents - these schools are attended by all students living in their catchment areas, more than a quarter of their students are in need of support measures due to their social disadvantage. Three other schools in the sample, Pear Tree Elementary, Plum Tree Elementary and Cherry Tree Elementary, are located in cities with greater school competition; for a variety of reasons, these schools are known as "Roma schools" in their neighborhoods and socially disadvantaged students constitute the majority of their student population. The last involved school, Apricot Tree Elementary, is located directly in a socially excluded area and is attended exclusively by socially disadvantaged Roma students.

The process of data creation was based on semi-structured interviews conducted at a distance, via a conference call in MS Teams or by phone. In each school, the interview was conducted with one or two participants who had the best overview of the issue in five cases the participants were school headteachers, in two cases the respondents were deputy headteachers and two interviews were conducted with special teachers. In total, there were nine interviews conducted, in the range of 17 to 35 minutes. With the consent of the participants, the interviews were recorded, and the records were subsequently converted into written form. The data analysis was based on a combination of open coding, which aims to reveal and name specific topics in data files (Hendl, 2008), and the technique of "laying out cards", in which the researcher organizes individual codes and categories into a line of related topics (Švaříček, Šed'ová et al., 2014).

The following part of the article presents the research results from the category"the role of the teacher assistants", in which the analysis was focused on the participants' statements about the support provided by teacher assistants during the distance education of socially disadvantaged Roma students.

\section{Results: Headteachers on the roles of teacher assistants during the Covid-19 era}

At the beginning of the quarantine in spring 2020, right after the school closures, many schools encountered barriers to getting in touch with the families of socially disadvantaged students. Some families did not live at their official addresses or had invalid

3 In order to ensure the research's ethical parameters and in accordance with the requirements for the anonymity of the research participants, the names of all research participants, as well as the designations of all participating schools, were changed. 
phone numbers. At this time, the important role of the teacher assistant was to establish contact with those families, to find out where they lived or what phone number they used. Teacher assistants who themselves are Roma had a strong advantage in their knowledge of students' families and their social background.

Matouš, deputy headteacher, Plum Tree Elementary School: "We also have Roma assistants and we used them in the initial contact when, as I say, we had not managed to find the families - the main thing with the assistants is their knowledge. Knowledge of who is related to whom, who to contact, probably they'll have a number for them, will know where they live, where they've moved to, with whom they live and so on."

After the online distance education had been set up, the teacher assistants were not only involved in organizing online lessons but were also in charge of contacting students who did not attend the online lessons. The teacher assistants' task was to get in touch with students or their parents, find out why they stayed offline and what the possible solutions were.

Petra, headteacher, Pear Tree Elementary School: "I know that in those other classes, the children couldn't connect if they had classes online, so the assistants called them by phone, and communicated with the families of the children, who just couldn't connect. Or then the older ones had the messenger groups, so the assistant tried to guide the children. They also addressed the questions of who, what, where, what to have or not to have..."

In relation to some socially disadvantaged students, it was almost impossible to organize classes online - many families, living in substandard housing or socially excluded areas, lacked not only the necessary technical equipment but also a sufficient internet connection. In these cases, it was necessary to provide teaching through printed learning materials and various worksheets, which were distributed partly by teacher assistants at school - the students or their parents had the opportunity to come to school, individually contact the teacher assistant, pick up the learning materials and, if needed, individually consult about the learning tasks.

Ivana, headteacher, Cherry Tree Elementary School: "We had a service at the reception where teachers and teacher assistants took turns, so there was always someone who was competent, who was able to give the task to parents and explain to them, tell them, ask questions, etc. So, some of the children were actually educated like this."

In communication with some of the socially disadvantaged Roma students and their families, it turned out that it was easier to distribute the learning materials not at schools, but directly in the localities they lived in. So the teacher assistants, equipped with various printed learning materials, set off to the neighboring excluded areas to take these materials to their students, to their mail boxes or directly to their homes.

Filip, headteacher, Walnut Tree Elementary School: "Assistants played a big part in the preparation of materials and in their distribution. If the parents could not pick up the materials, because of illness, for example, we did not want to send someone unknown, so the assistants participated in distributing the materials to the children. So that's how they were involved..." 
Some schools also used the teacher assistants to distribute the learning materials sent by teachers who had ended up in quarantine or who used to commute from a greater distance and worked from home during the school closures.

Jana, special teacher, Walnut Tree Elementary School: "There are a lot of teachers who commute, maybe 20, 25 kilometers. So they sent the materials to the assistants, or somehow agreed with them, and they, the assistants, distributed them here... it was from several teachers, where we used the assistants in this way."

In those families of socially disadvantaged students who had the necessary technology to engage in online learning - which usually meant having a useable smartphone and adequate data credit - teacher assistants also helped to solve problems related to an insufficient knowledge of teaching software. Many students, as well as their parents, did not know how to connect to the right program and how to get in touch with the teacher, so it was also necessary to help them in this way.

Jana, special teacher, Walnut Tree Elementary School: ".. For example, it was a dysfunctional family, or they were not completely socially and technically capable. Often the parents had problems similar to the children. So the assistants also got involved a lot there, they were very active there."

Sometimes, when students did not have anyone at home to help them with their schoolwork, and it was not possible to help them online, some schools provided individualized personal consultations - always only one-to-one and in compliance with all hygiene measures. Teacher assistants were also involved in these consultations and provided support to socially disadvantaged Roma students in solving tasks that the students themselves could not cope with.

Johana, headteacher, Apple Tree Elementary School: "One to one. When, in fact, either the special teacher herself or the teacher assistant were in charge, and the children went there according to the given schedule. They were always in direct contact with the school's employee for one hour of the week. And they helped them work with the written materials that the teachers gave them, or they worked on some of their things, as they did at the time when they went to school."

In normal times, when students are allowed to be present at schools, the tutoring of socially disadvantaged Roma students is an important tool for minimizing the risk of their school failure. During the school closure period, some teacher assistants tried to offer online tutoring, at least to those students who had the necessary equipment and were able to use it.

Petra, headteacher, Pear Tree Elementary School: "So when they did, the children then had tutoring, again through these online meetings. But it depended on whether the children or even the assistant, whether they were capable of it or not."

Even in May, when government measures were eased and students were again allowed to be present in schools, the teacher assistants provided significant support in managing the entire educational process. For many schools the situation was very 
difficult, because presence at school was voluntary for the students and some of them thus remained at home; it was therefore necessary to provide both personal and online teaching at the same time. In order to apply the hygienic measures, it was also important to separate students into the smallest possible groups. The teacher assistants in schools helped to organize students into small groups and manage their education.

Johana, headteacher, Apple Tree Elementary School: "So we arranged groups to get the roughly forty most vulnerable children in school, including the twenty Roma children. Because there are other socially disadvantaged families, but of non-Roma origin. And actually, the second limit was that our school, although large - has many smaller buildings, so the classrooms are relatively small. In order to meet the requirements, we actually set up groups of eight children. So, in fact, five groups of eight students were formed, where we set up one group from a very large family, where we knew that they were in contact with each other anyway. And the teaching took place in the morning at school and it was carried out by a teacher assistant."

The last, but not least, important role of the teacher assistant was to carry out instruction for students who were personally present in school while the teacher was teaching online.

Filip, headteacher, Walnut Tree Elementary School: "... So the assistant was in class, actually on the front-line, because we didn't know how long it would take before someone would get infected. A teacher getting infected creates a great vacuum for all the children. But if the assistant gets infected, we can still manage it somehow. So the assistants, who were not afraid, went on the so-called front-line, directly working with the children, while the teachers were teaching online, from their homes. And others, who were not directly involved, got involved in whatever way was needed. In the end, based on this experience, one assistant decided that she would really like to start teaching, and she has now taken over one class and she is enrolling at the Faculty of Education to finish her education. So we have made the most of it."

\section{Discussion \& Conclusion}

In earlier studies, such as Němec et al. $(2015,2018)$, the benefits of the teacher assistant's role in the education of socially disadvantaged Roma students under normal non-pandemic - conditions were described in detail. Current research shows that the position of teacher assistants is also very important during distance learning. This corresponds to the findings of the Czech School Inspectorate (2020), which - in its study on schools during the pandemic - also identified teacher assistants as essential support for the education of socially disadvantaged students.

During distance learning, students do not attend school and it is therefore extremely important to ensure alternative contact between the school and the students' 
families. However, as Guerra and Leitão (2020) emphasize, it is important for Roma students that the contact with the family respects the specifics of Roma culture and also considers the local social conditions. In this context, teacher assistants represent a very important element of the educational system, as they are often very well informed about the cultural differences of socially disadvantaged Roma families as well as about the local social specifics.

The support provided by the teaching assistants during distance learning does not have to be of an educational nature only. Studies by Hoffman and Miller (2020) and Roca et al. (2020) show how important schools can be in the field of students' mental health and the prevention of domestic violence and suggest that these non-academic functions of schools should also be taken into account in distance education. In this area, the teacher assistants' contact with students, whether online or in person, can also be a very important source of support for the students' overall situation.

During a pandemic, the role of teacher assistants can also be important during the weeks when the schools remain open and the students are allowed to learn in person: In order to minimize the potential for the transmission of infection, Poletti (2020) recommends organizing the educational process in the form of group activities with smaller numbers of students, and in many schools this is only feasible when some students are being educated by a teacher and, at the same time, other students work under the supervision of a teacher assistant.

Last but not least, some risks associated with the use of teacher assistants need to be mentioned: For example, Butt (2016) points to the lower qualification of teacher assistants, who cannot fully substitute more qualified teachers in the education of students with special educational needs. ${ }^{4}$ Similarly, Starčević, Dimitrijević and MacuraMilovanović (2016) point out that more intensive communication between the teacher assistant and the parents of socially disadvantaged Roma students may lead to a decrease in the teacher's involvement in communication with these parents. And although none of these risks were mentioned in the presented research, it is necessary to ensure under normal conditions as well as during distance learning - that teacher assistant have sufficient guidance from qualified teacher, that the support provided by a teacher assistant does not mean a reduction in support from the teacher and that both of them, teacher and assistant, work with the socially disadvantaged Roma students as much as possible.

To conclude, it is evident that teacher assistants represent a very important tool in the education of socially disadvantaged Roma students and that the distant education of these students would be much more difficult and much less successful without the assistants' support. In future research, it would be useful to focus attention on the

4 Although during the pandemic, the roles and responsibilities of both professions - teacher assistants and teachers - were closer than ever before. 
potential overlaps of pedagogical and social activities in the work of assistants and to verify partial research findings in a quantitative manner on larger groups of assistants.

\section{References}

Butt, R. (2016). Teacher Assistant Support and Deployment in Mainstream Schools. International Journal of Inclusive Education, 20(9), 995-1007.

Czech School Inspectorate (2020). Vzdělávání na dálku v základních a středních školách. Tematická zpráva. [Distance education in primary and secondary schools. Thematic report.] Retrieved from: https://www.csicr.cz/cz/Aktuality/Tematicka-zprava-Vzdelavani-na-dalku-v-ZS-a-SS

Charvát, P., Lang, P., Staveník, A. (2020). Spolupráce škol se žáky, kteří žijí ve složitých životních podmínkách, v čase opatření príijatých v souvislosti s šířením Covid-19. [Cooperation between schools and pupils living in difficult living conditions at the time of the measures implemented with the regard of spread of Covid-19] e-Pedagogium, 20(3), 9-31. DOI: 10.5507/epd.2020.018.

Decree no. 27/2016 Coll. „Vyhláška č. 27/2016 Sb. o vzdělávání žáků se speciálními vzdèlávacími potřebami a žáků nadaných" ["Decree no. 27/2016 Coll., on education of pupils with special educational needs and talented pupils"], Sbírka předpisů České republiky, No. 10, 2016. Ve znění pozdějších novelizací. [Collection of regulations of the Czech Republic, No. 10, 2016. As amended]

Education Act. Zákon č. 561/2004 Sb. o předškolním, základním, středním, vyšším odborném a jiném vzdělávání (školský zákon) [“Act no. 561/2004 Coll. on preschool, primary, secondary, higher professional and other education (Education Act)"], Sbírka zákonů České republiky, No. 190, 2004. Ve znění pozdějších novelizací. [Collection of Laws of the Czech Republic, No. 190, 2004. As amended.]

GAC s. r. o. (2015). Analýza sociálně vyloučených lokalit v ČR. [Analysis of socially excluded localities in the Czech Republic.] Prague: Ministry of Labor and Social Affairs of the Czech Republic.

Government Council for Roma Minority Affairs (2019). Zpráva o stavu romské menšiny v České republice za rok 2018. [Report on the State of the Roma Minority in the Czech Republic in 2018]. The Government Council for Roma Minority Affairs, online cit. 2019-11-05.

Guerra, J., Leitão, C. (2020). Roma Children Going to Primary School: The Contribution of Interagency Working to Support Inclusive Education. Orbis Scholae, 13(3), 25-38. https://doi.org/ 10.14712/23363177.2019.26.

Hájková, V. et al. (2018). Asistent pedagoga. Profese utvářená v dialogu. [Teaching assistant. A profession formed in dialogue]. Prague: Karlova Univerzita, Pedagogická fakulta.

Hendl, J. (2008). Kvalitativní výzkum: základní teorie, metody a aplikace. [Qualitative research: basic theories, methods and applications]. $2^{\text {nd }}$ updated ed. Prague: Portál.

Hoffman, J. A., Miller, E. A. (2020). Addressing the Consequences of School Closure Due to COVID-19 on Children's Physical and Mental Well-Being. World Medical and Health Policy. DOI: 10.1002/ wmh3.365.

MŠMT. [Ministry of Education, Youth and Sports of the Czech Republic], Statistické ročenky školstvíVýkonové ukazatele. [Statistical Yearbooks of Education - Performance Indicators]. Online, accessed 2020-11-29. Retrieved from http://toiler.uiv.cz/rocenka/rocenka.asp

Němec, Z., Hájková, V., Květoňová, L., Strnadová, I. (2018) The role of teaching assistants in the education of students from ethnic minorities in the Czech Republic. In Goméz Chova, L., López Martínez, A., Candel Torres, I. (Eds.). ICERI 2018. Proceedings 11th International Conference of Education, Research and Innovation November 12th-14th, 2018 - Seville, Spain. Seville: IATED Academy, 2018. pp. 8407-8413. 
Němec, Z., Šimáčková-Laurenčíková, K., Hájková, V., \& Strnadová, I. (2015). When I need to do something else with the other children, then I can rely on her: teaching assistants working with socially disadvantaged students. European Journal of Special Needs Education, 30(4), 459-473. https://doi.org/10.1080/08856257.2015.1035904

Němec, Z. et al. (2014). Asistence ve vzdělávání žáků se sociálním znevýhodněním. [Assistance in education of socially disadvantaged pupils.] Prague: Nová škola o.p.s.

Němec, Z.; Šimáčková-Laurenčíková, K.; Hájková, V. (2014). Asistent pedagoga v inkluzivní škole. [A teaching assistant in an inclusive school.] Prague: Karolinum.

Poletti, M. (2020). 'Hey teachers! Do not leave them kids alone! Envisioning schools during and after the coronavirus (COVID-19) pandemic'. Trends in Neuroscience and Education, 20. doi: 10.1016/j.tine.2020.100140.

Roca, E.; Melgar, P.; Gairal-Casadó, R., \& Pulido-Rodríguez, M. A. (2020). Schools that "open doors" to prevent child abuse in confinement by COVID-19. Sustainability, 12(11). https://doi.org/ $10.3390 /$ su12114685

Starčević, J., Dimitrijević, B., \& Macura-Milovanović, S. (2016). Rethinking the Role of Pedagogical Assistants: Establishing Cooperation between Roma Families and Schools in Serbia. Center for Educational Policy Studies Journal, 6(4), 73-91.

Švaříček, R., Šed’ová, K. et al. (2014). Kvalitativní výzkum v pedagogických vědách [Qualitative research in educational sciences]. $2^{\text {nd }}$ ed. Prague: Portál.

\section{Contact:}

PhDr. Zbyněk Němec, Ph.D.

Special Education dept., Faculty of Education, Charles University,

Magdalény Rettigové 4, 11639 Prague 1

e-mail: zbynek.nemec@pedf.cuni.cz

PhDr. Zbyněk Němec, Ph.D. is a special pedagogue, he works as an assistant professor at the Faculty of Education at the Charles University in Prague. In the past, he had worked for ten years as a teacher with pupils with special educational needs and school counselling for two years. For more than seven years, he has been cooperating with the public benefit company Nová škola - a non-profit organization dedicated to supporting the education of socially disadvantaged and Roma pupils. He is a member of the Czech Professional Society for Inclusive Education. 